\title{
Application of geoinformation techniques to determine zones of sediment resuspension induced by wind waves in lakes (using two lakes from Northern Poland as examples)
}

\author{
Elżbieta Bajkiewicz-Grabowska, Maciej Markowski, Krzysztof Lemańczyk \\ Department of Limnology, University of Gdańsk, Bażyńskiego 4, 80-952 Gdańsk, Poland, e-mail: bajka37@wp.pl; geomma@ug.edu.pl \\ (corresponding author); krzychu@lemanczyk.com
}

\begin{abstract}
Resuspension in lakes affects the quality of lake water. It is possible to model this process and visualize its outcomes using GIS tools. An assessment of the size of the zone of sediment resuspension was made for two lakes located in Northern Poland threatened by rapid eutrophication. For each of the lakes, four simulations using two methods for determining the effective wind length $(F)$ (Model 1 and Model 2) and two methods for determining the wind wavelength $\left(L_{w}\right)$ (Model A and Model B) were performed. The analysis, taking into account the morphometry of the studied lakes and anemometric conditions, indicated that the differentiator is the applied simulation method of calculating the wavelength caused by the wind. The analysis is theoretical in nature and the results need to be verified in the field..
\end{abstract}

Key words: wind resuspension, sediments, water quality, fetch, wind waves

\section{Introduction}

When deciding which method to use for restoring a lake ecosystem to good ecological status, environmental pressures (natural and anthropogenic) on that ecosystem must first of all be assessed (Bajkiewicz-Grabowska 1981, 1983, 1985, 2002, 2010) and, based on this assessment, the sources responsible for the ecosystem's status are identified. These are mainly external sources, i.e. the area of land providing influx of water and biogenic matter to the lake (the lake's catchment) together with the lake users (humans and birds), although sources responsible for the so-called internal loading (e.g. Boström et al. 1982; Wiśniewski 1995; Kajak 1998) can also significantly contribute to the lake's trophic state and ecological condition (e.g. Bajkiewicz-Grabowska 2015). The magnitude of the lake's internal loading depends on the amount of organic matter deposited in lake-bed sediment and nutrient content. Products of decomposition of this organic matter can re-enter the circulation in the lake (e.g. by resuspension) as secondary loads and markedly accelerate the process of eutrophication (e.g.
Wiśniewski 1995; Van Hullebusch et al. 2003; Watts 2000). Multiple cases of deterioration in lake water quality caused by sediment resuspension have been reported (Bengtsson and Hellström 1992; Kristensen et al. 1992; Søndergaard et al. 1992; James and Barko 1994; Ekholm et al. 1997; De Vicente et al. 2006).

Resuspension of lake-bed sediment may be driven by wind-induced waves (or wind waves) (Ward 1980; Leuttich et al. 1990; Bachmann et al. 2000; Douglas and Rippey 2000).Based on studies that differed in terms of morphometry, water dynamics and trophic state, it has been concluded that wind-induced resuspension of sediment plays an important role in the oxygen balance of shallow lakes and the littoral zones of deep lakes (e.g. Wiśniewski 1995). Wind waves propagated to the shear stress zone along the bottom of the lake set in motion water currents sufficient to resuspend fine lake-bed sediments and interstitial waters which could result in significant amounts of phosphorus being loaded to the overlying waters.

The modelling of the impact of wind waves on resuspension of lake-bed sediment has long been a well-known topic in the literature. A significant con- 
tribution to this field has been made by the research conducted by Håkanson (1977) and by the Coastal Engineering Research Center (CERC) of the US Army Corps of Engineers (1975, 1977, 1984, 2002), which have subsequently been used by many authors as the basis for modelling resuspension in lakes, for instance, in the United States (Carper and Bachmann 1984; Hawley and Lesht 1992; Hamilton and Mitchell 1996; Bachmann et al. 2000), Argentina (Cozar et al. 2005) and Holland (Eleveld 2012).

As the factors responsible for wind-induced resuspension of lake-bed sediment - namely the lake area, shape and bathymetry, and the wind conditions - are all spatial in nature, it is possible to model this process and visualise its outcomes using GIS tools (Laenen and Le Tourneau 1996). The process of lakebed sediment resuspension modelling usually requires multiple repetitive mathematical operations to be performed, which, in turn, necessitates the use of computer programming elements, or scripting, in research studies. This, however, provides a fast and simple way of carrying out a large number of analyses on a large number of cases.

The aim of this paper is to demonstrate the possibility of applying selected hydrodynamic models for the modelling of lake-bed sediment resuspension using GIS tools. This approach allows the zones of the lake in which wind-induced resuspension of sediment can occur under specific wind conditions to be identified. As a result, combining hydrodynamic models with the functionalities and possibilities offered by GIS tools provides a ready-to-use method which can be routinely applied to assess environmental pressures on lake geoecosystems.

\section{Study area}

This was a methodology study. We selected two lakes in Pomeranian Lakeland (Polish Lowland) as the study objects: Lake Wielgie (Dobiegniewskie) and Lake Otalżyno (Fig. 1). Lake Wielgie (Dobiegniewskie) is located in the central part of Dobiegniewskie Lakeland, in the River Drawa basin (part of the River Oder basin). The Mierzęcka Steam, a tributary of the River Drawa, flows through the lake. The lake has an elongated shape and the major axis of its basin runs in a southwest-northeast direction. Lake Wielgie is a medium-sized (136.9 ha) and very shallow (mean depth: 2.2 $\mathrm{m}$; maximum depth: $6.8 \mathrm{~m}$ ) water body. This polymictic lake is an urban body of water (its southwest part lies within the confines of the town of Dobiegniew) and its direct catchment is under agricultural use (BajkiewiczGrabowska and Markowski 2014). Being an urban body of water, the lake had been the recipient of municipal wastewater effluents for many years.

Lake Otalżyno is located in the eastern part of Kashubian Lakeland, in the Reda River basin. It is a small (80.73 ha) and very shallow (mean depth: $1.2 \mathrm{~m}$, maximum depth: $5.9 \mathrm{~m}$ ), therefore polymictic, lobelia lake. The ratio of the lake's length to its maximum width is only 1.4 , which indicates an oval shape. This is in contrast to Lake Wielgie, whose length-to-maximum-width ratio is 4.3. The land use in the direct catchment of Lake Otalżyno includes pastures and cropland (Markowski and Kwidzińska 2015).

In terms of environmental pressures, Lake Otalżyno and Lake Wielgie both represent type IV lake geoecosystem (Bajkiewicz-Grabowska and Markowski 2014; Markowski and Kwidzińska 2015). They are water bodies characterised by catchments whose natural features favour non-point source pollution, and the lakes are largely susceptible to external influences. Both lakes are therefore at a high risk of rapid progression of eutrophication.

\section{Methods}

Resuspension of sediment is a result of multiple processes and phenomena that occur directly in water (bottom fish feeding, hydrochemical processes) or at the water/air (wind) interface. Wind waves, which are principally driven by wind blowing along the lake, are one of the best recognised factors that intensify resuspension of lake-bed sediment. Depending on the relationship between its wavelength $\left(L_{w}\right)$ and the water depth $(d)$, a wave may be classified as a deep-water wave or a shallow-water wave. If one-half of its wavelength $\left(L_{w} / 2\right)$ is less than the water depth $(d)$, the wave can be considered a deep-water wave $\left(L_{w} / 2<d\right)$, otherwise it is classified as an intermediate-water wave (transitional-water wave) or a shallow-water wave (CERC 1975, 1984; Bajkiewicz-Grabowska and Mikulski 1999). Resuspension of sediment is usually caused by shallow-water waves that reach the lake bottom.

The wave base (Fig. 2) separating the area where sediment resuspension occurs from the area where no resuspension takes place can be determined from mathematical formulae (Smith and Sinclair 1972; Håkanson 2004) or based on the thermocline depth (Wetzel 2001). 


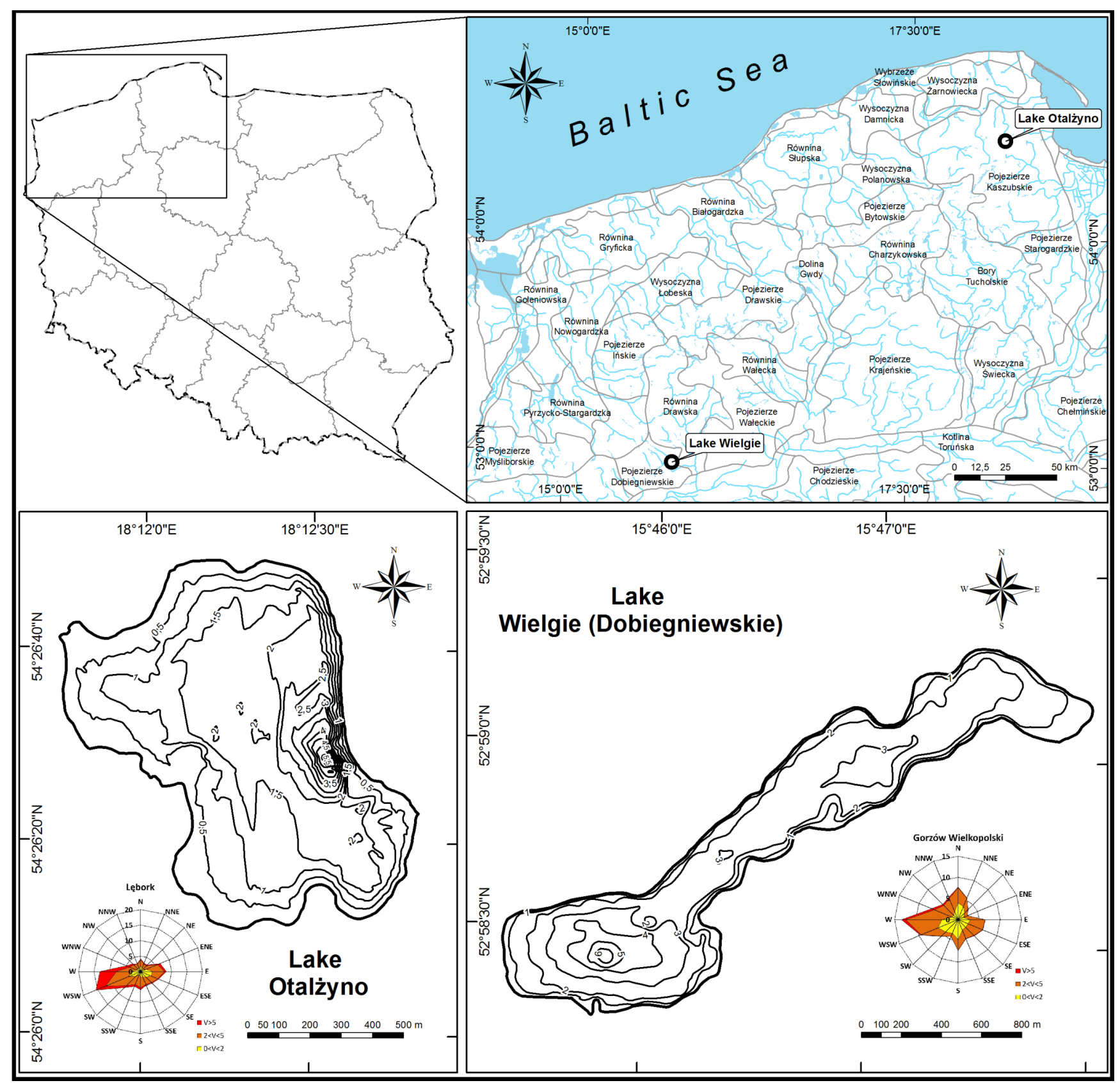

Fig. 1. Location and bathymetry of the studied lakes, Lake Otalżyno and Lake Wielgie (Dobiegniewskie)

For the purposes of our study we assumed that resuspension of lake-bed sediment was caused by shallow-water waves (Carper and Bachmann 1984; Laenen and Le Torneau 1996; Booth et el. 2000; Sarà 2009). The plane separating the area of sediment resuspension from the area with no sediment resuspension would therefore be at a water depth corresponding to one-half of the wind wave wavelength $\left(d=L_{w} / 2\right)$. The wind wave wavelength depends, in turn, on the wind fetch, i.e. the distance the wind blows over the water in generating the wave. This is the so-called effective length $(F)$.

Wind wave wavelength and wind fetch were calculated using two models recommended by the CERC $(1975,1984,2002)$ and by the Beach Erosion Board (BEB) (1962).

Model A was originally developed for deep-water waves but has also been successfully used for shallow lakes (Carper and Bachmann 1984; Scheffer 1998; 


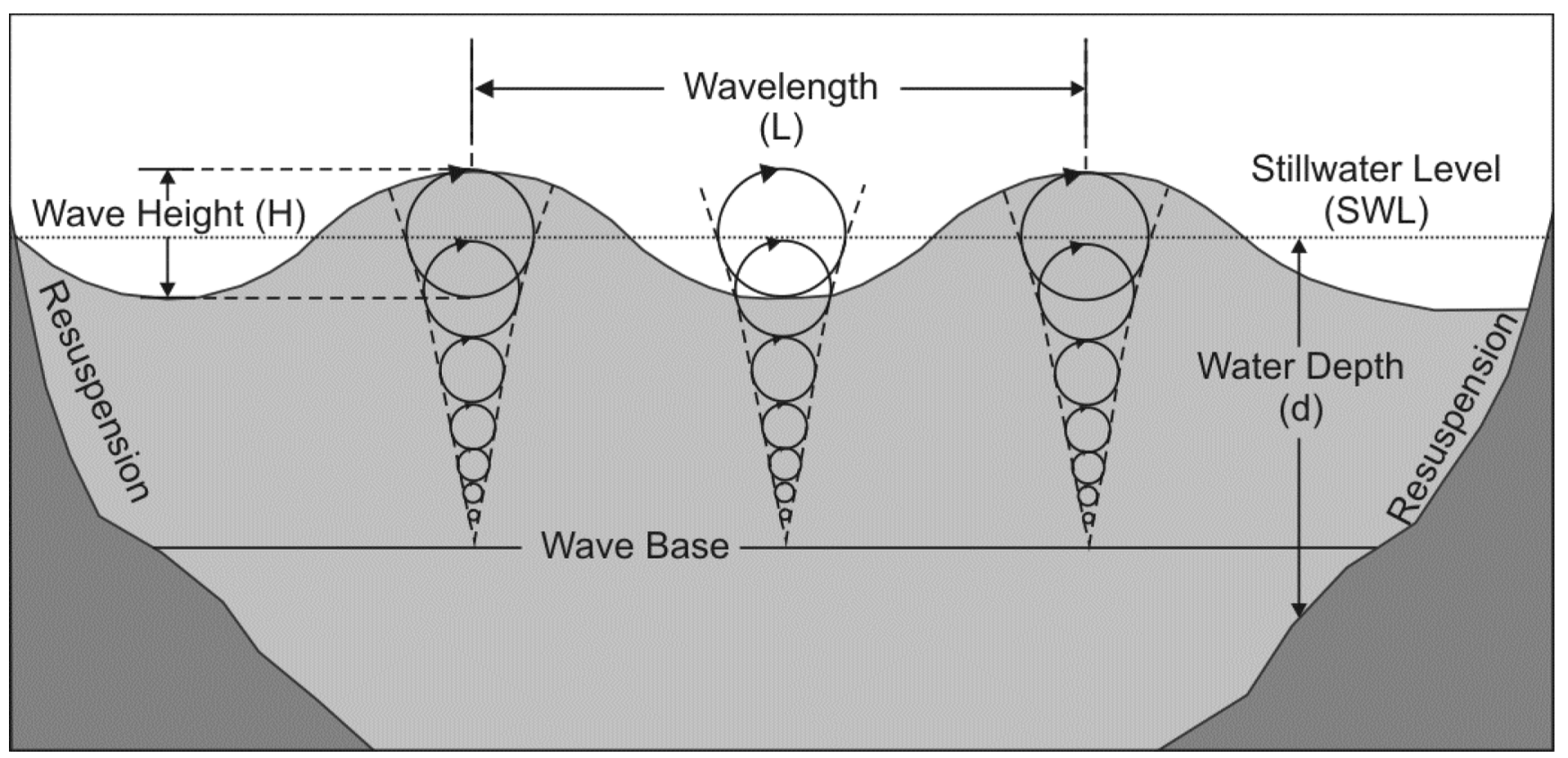

Fig. 2. Diagram illustrating the basic parameters of wind waves used to determine resuspension areas in lakes

Bachmann et al. 2000; Nagid et al. 2001; Sarà, 2009). Wind wave wavelength in this method is calculated from the following formulae (CERC 1975):

$$
\begin{aligned}
& L_{w}=\frac{g T^{2}}{2 \pi}, \\
& \frac{g T^{2}}{2 \pi}=1.20 \tanh \left[0.077\left(\frac{g F}{U^{2}}\right)^{0.25}\right]
\end{aligned}
$$

where: $L_{w}$ is the wind wave wavelength $(\mathrm{m}), g$ is normal gravitational acceleration $\left(9.8 \mathrm{~m} \mathrm{~s}^{-2}\right), T$ is the wave period (s), $U$ is the wind speed $\left(\mathrm{m} \mathrm{s}^{-1}\right)$, and $F$ is the effective fetch length $(\mathrm{m})$.

Model B was originally developed for predicting shallow-water waves but has also been tested for shallow lakes (e.g. Hamilton and Mitchell 1996; Laenen and Le Tourneau 1996). Wind wave wavelength in Model B is calculated from the following formulae (CERC 1984):

$U_{A}=0.71 U^{1.23}$,
$L_{w}=\frac{g T^{2}}{2 \pi} \tanh \left(\frac{2 \pi d}{L_{w}}\right)$

where: $U_{A}$ is the wind stress factor (adjusted wind speed), and $d$ is the depth of the water body (m).

In both models, the element of considerable significance for the wavelength at a given point in the lake is the effective fetch length $(F)$. Two methods are used to determine effective fetch length. The methods are generally similar and the only difference is in the parameters used. In both methods, for each of the analysed points on the lake surface and shoreline, a specific number of radials spread around the wind direction are determined (e.g. Station 1 in Fig. 3). The central radial indicates the major wind direction and represents the maximum effective wind fetch length $\left(F_{\max }\right)$. The remaining radials are spread around the central radial at fixed angle intervals of 6 or 3 degrees, depending on the method. For each radial, the unobstructed distance that wind can travel over water is

$\frac{g T}{U_{A}}=7.54 \tanh \left[0.833\left(\frac{g d}{U_{A}^{2}}\right)^{3 / 8}\right] \tanh \left\{\frac{0.0379\left(\frac{g F}{U_{A}^{2}}\right)^{1 / 3}}{\tanh \left[0.833\left(\frac{g d}{U_{A}^{2}}\right)^{3 / 8}\right]}\right\}$,(4) 


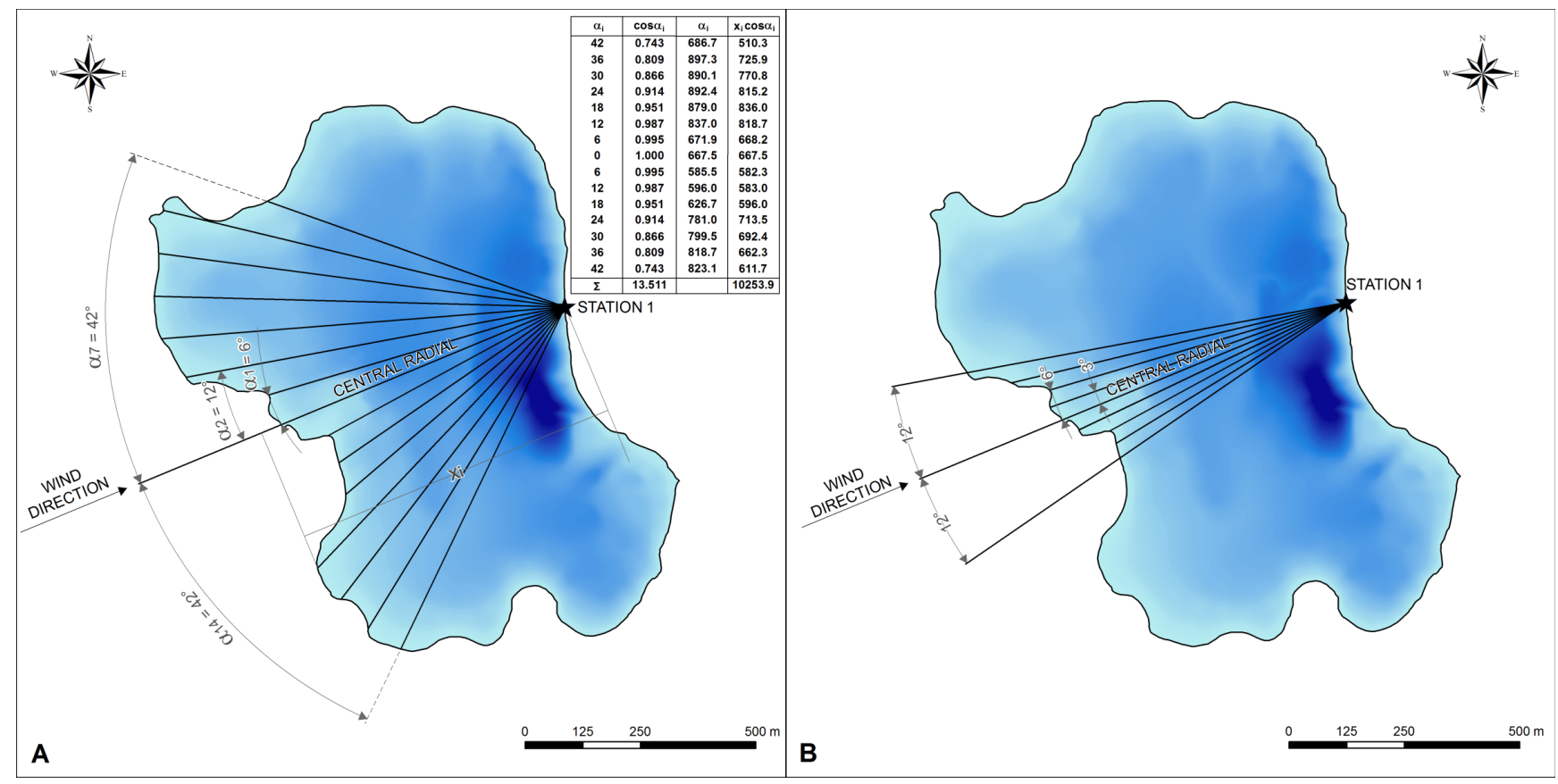

Fig. 3. Effective fetch $(F)$ determined using two different models: (A) proposed by the Beach Erosion Board in 1962 (BEB 1962) (Model 1) and (B) proposed by the Coastal Engineering Research Center in 1984 (CERC 1984) (Model 2)

determined, i.e. the distance from a given point on the lake to the shoreline (land or island).

The method proposed by the BEB (1962) (Fig. $3 \mathrm{~A}$ ) uses 15 radials whose deviation angle $a$ is, respectively: $\pm 6,12,18,24,30,36$ and 42 degrees (Model 1). Effective length defined according to this method is calculated from the following formula:

$$
F=\frac{\sum_{i=0} x_{i} \cdot \cos \alpha_{i}}{\sum_{i=0} \cos \alpha_{i}}=\frac{\sum_{i=0} x_{i} \cdot \cos \alpha_{i}}{13,512}
$$

where: $F$ is the effective length $(\mathrm{m}) ; \alpha_{i}$ is the deviation angle $\left({ }^{\circ}\right) ; x_{i}$ is the length of the individual radial measured to the land or island (parallel to the central radial) $(\mathrm{m})$.

The other method, developed by the CERC (2002), uses only 9 radials spread around the wind direction at 3-degree increments on both sides over an arch of 12 degrees (Model 2). Effective length in this method is the arithmetic mean of the lengths of all the radials (Fig. 3B).

The reference stations were determined in ArcGIS using the Thiessen polygon method from where wind data for Lake Otalżyno and Lake Wielgie were obtained. The wind direction and speed tables for Lake Otalżyno and for Lake Wielgie used data from the station in Lębork and the station in Gorzów Wielkopol- ski, respectively. The wind data covered the ten-year period from 2001 to 2010. Based on these data directional wind roses were compiled (Fig. 1), and the mean wind speed for the predominant wind direction was calculated for the ten-year period from 2001 to 2010 . The predominant wind direction and the mean wind speed for Lake Otalżyno were $247.5^{\circ}$ (WSW) and 3.60 $\mathrm{m} \mathrm{s}^{-1}$, respectively, and those for Lake Wielgie were $270^{\circ}(\mathrm{W})$ and $3.35 \mathrm{~m} \mathrm{~s}^{-1}$, respectively.

Four simulation methods were compiled (1A, $1 \mathrm{~B}, 2 \mathrm{~A}$ and $2 \mathrm{~B}$ ) to determine the impact of wind waves on the lake bed in both lakes in terms of inducing resuspension of lake-bed sediment (Table 1).

Determination of the zones in both lakes where resuspension of lake-bed sediment was possible using ArcGIS, for which a Python script performing individual calculations had been written. A diagram of these calculations is shown in Figure 4. The script requires

Table 1. Methods for estimating the formation of lake-bed sediment resuspension

\begin{tabular}{cccc}
\hline & \multicolumn{2}{c}{ Wavelength $\left(L_{w}\right)$} \\
\cline { 3 - 4 } & $\begin{array}{c}\text { Model A } \\
\text { CERC (1975) }\end{array}$ & $\begin{array}{c}\text { Model B } \\
\text { CERC (1984) }\end{array}$ \\
\hline \multirow{2}{*}{$\begin{array}{c}\text { Wind } \\
\text { fetch }(F)\end{array}$} & $\begin{array}{c}\text { Model 1 } \\
\text { BEB (1962) }\end{array}$ & 1A & 1 B \\
\cline { 2 - 4 } & $\begin{array}{c}\text { Model 2 } \\
\text { CERC (2002) }\end{array}$ & 2 A & 2 B \\
\hline
\end{tabular}




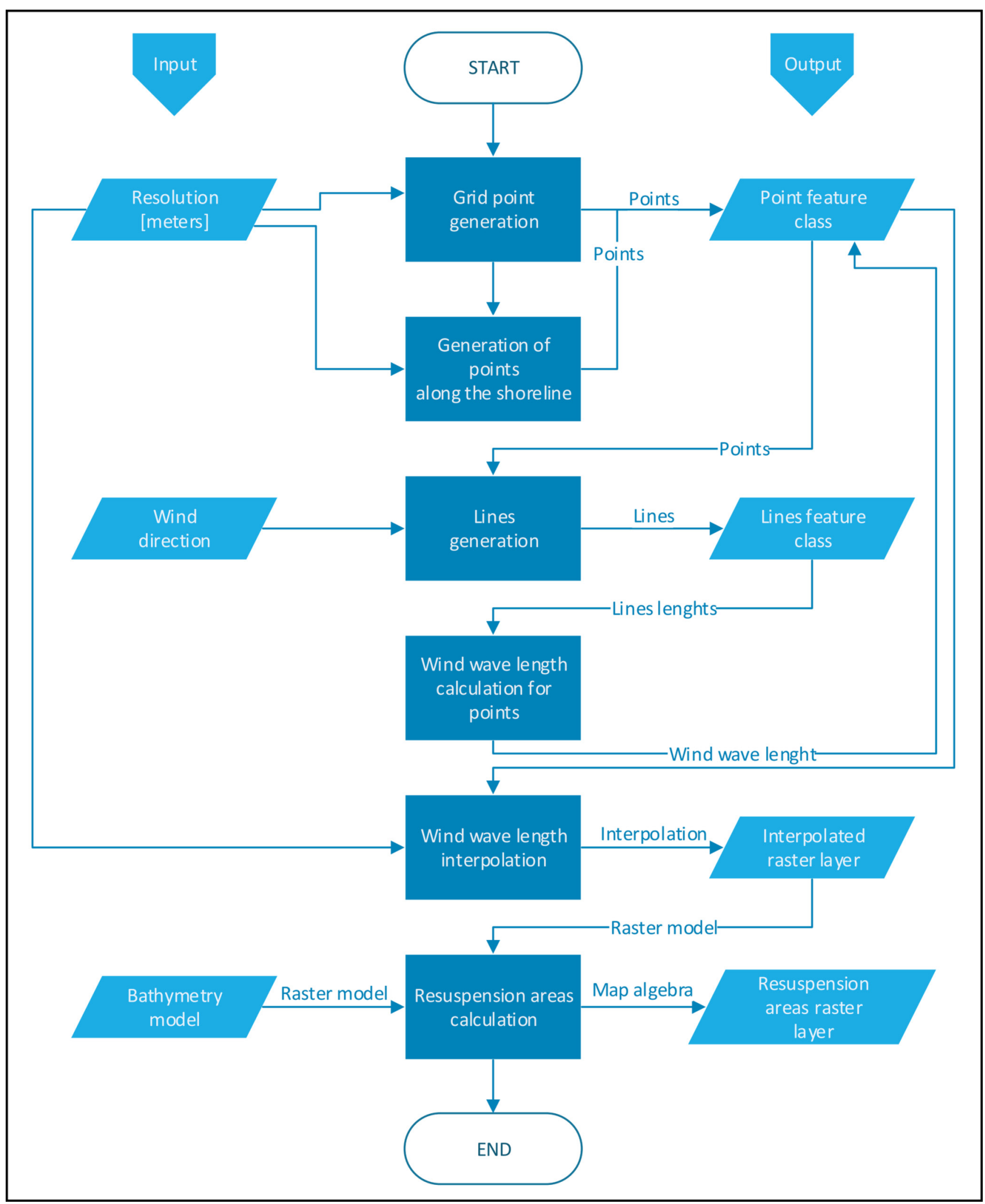

Fig. 4. Flow diagram illustrating the procedure of determining resuspension areas using ArcGIS software and the Python scripting language 
two geometric input components: a digital model of the lake bed (the model was generated based on a bathymetric chart) and a single polygon object representing the contour of the water body (the shoreline). Supplementary parameters necessary for performing the calculations are: the wind direction, the wind speed, and the mesh size of the grid of points generated for depth sampling and for determining the collections of radials. The first step is to generate a regular grid of points of predefined density (spacing) for the lake surface. We used a $50 \times 50 \mathrm{~m}$ grid. As the shoreline is also used for predicting wind fetch, points located on the shoreline should also be included in the grid of points. The distance between these points is equal to the grid size defined in the previous step. (i.e. $50 \mathrm{~m}$ ). From each grid point, a collection of radials spread around at fixed angle increments $\alpha_{i}\left(6^{\circ}\right.$ or $\left.3^{\circ}\right)$ is generated in the opposite direction to the wind direction. For each radial, according to the adopted models ( 1 and 2), the distance between the grid point and the point of intersection of this radial with the lake shoreline is calculated. The resulting segment defines the wind fetch length for the grid point along the radial. Based on the length of each line starting at the grid point, effective wind fetch length $F$ is calculated for the given point according to the adopted model ( 1 or 2 ). For each point, the wind wave wavelength is calculated according to the adopted model (A or B). The resulting wavelength values for each of the generated points are used to create a continuous (interpolated) layer of wind wavelength $\left(L_{w}\right)$ variability distribution. This layer is created using one of the interpolation methods, e.g. ordinary kriging. From the raster format of the output file obtained after interpolation together with the raster format of the digital lake bed model, it is possible to determine the sites of sediment resuspension. According to the adopted methodology, resuspension occurs in those locations where one-half of the wavelength $L_{w / 2}$ is less than the water depth (d). The Map Algebra module of ArcGIS is used for this purpose. With this module it is possible to perform mathematical operations on raster files.
As a result, a raster image with two values is generated, where 0 is assigned to locations without resuspension taking place and 1 is assigned to areas where resuspension is taking place (Fig. 5). The resulting output file can be used for further raster analyses or can be easily and quickly converted to a vector file, which may be used in a number of vector analyses.

\section{Results}

The geoinformation analyses, in which the morphometry of both study lakes and the wind conditions recorded at the reference weather stations were taken into account, allowed us to identify potential areas of lake-bed sediment resuspension in Lake Wielgie and Lake Otalżyno (Fig. 5). The methodology that we adopted, apart from the wind component, does not take into account any other external factors that could affect the generation of wind-induced waves in these lakes (landform, land cover/use of land, impact of littoral vegetation, etc.).

For each of the lakes, we performed four simulations using two methods for determining the effective wind length $(F)$ (Model 1 and Model 2) and two methods for determining the wind wave wavelength $\left(L_{w}\right)$ (Model A and Model B) (Fig. 5).

As a result of these simulations, we obtained raster maps depicting the area of the lake where sediment resuspension was possible. We used the raster map to calculate the area of the lake bed (a projection of the lake bed onto the water surface) that could be subjected to resuspension processes. We then converted the resulting values to the percentages of the total lake areas subjected to wind-induced resuspension.

For both lakes, the highest percentages of the lake-bed area undergoing resuspension were obtained when the wind wave wavelength was calculated using Model A. Depending on the model used to determine the effective wind length (Model 1 or Model 2), these percentages for Lake Otalżyno were 16.3 and $14.3 \%$, respectively (Table 2).

Table 2. Surface area $(A)$, mean depth $\left(h_{m}\right)$, dynamic ratio $(D R)$ and the percent of bottom sediment resuspension received using different methods $(1 \mathrm{~A}, 1 \mathrm{~B}, 2 \mathrm{~A}, 2 \mathrm{~B})$

\begin{tabular}{|c|c|c|c|c|c|c|c|}
\hline \multirow{3}{*}{ Lake } & \multirow{2}{*}{$A$} & \multirow{2}{*}{$h_{m}$} & \multirow{2}{*}{$D R$} & \multicolumn{4}{|c|}{ Methods } \\
\hline & & & & $1 \mathrm{~A}$ & 1B & $2 \mathrm{~A}$ & $2 \mathrm{~B}$ \\
\hline & {$\left[\mathrm{km}^{2}\right]$} & {$[\mathrm{m}]$} & {$\left[\mathrm{km} \mathrm{m}^{-1}\right]$} & \multicolumn{4}{|c|}{ [\%] } \\
\hline Lake Otalżyno & 0.81 & 1.2 & 0.75 & 16.3 & 3.0 & 14.9 & 3.0 \\
\hline Lake Wielgie (Dobiegniewskie) & 1.30 & 2.2 & 0.52 & 8.8 & 2.6 & 10.1 & 3.0 \\
\hline
\end{tabular}




\begin{tabular}{|c|c|c|}
\hline Methods & Lake Otalżyno & Lake Wielgie (Dobiegniewskie) \\
\hline $\begin{array}{l}\text { 1A } \\
\mathrm{F} \text { - Beach Erosion } \\
\quad \text { Board (1962) } \\
\mathrm{L}_{w}-\text { Coastal Engineering } \\
\text { Research Center (1975) } \\
\text { - deep-water wave }\end{array}$ & & \\
\hline $\begin{array}{l}\text { 1B } \\
\text { F- Beach Erosion } \\
\text { Board (1962) } \\
\mathrm{L}_{w} \text { - Coastal Engineering } \\
\text { Research Center (1984) } \\
\text { - shallow-water wave }\end{array}$ & & \\
\hline $\begin{array}{l}\text { 2A } \\
\text { F - Coastal Engineering } \\
\text { Research Center (2002) } \\
\mathrm{L}_{\mathrm{w}} \text { - Coastal Engineering } \\
\text { Research Center (1975) } \\
\text { - deep-water wave }\end{array}$ & & \\
\hline $\begin{array}{l}\text { 2B } \\
\text { F - Coastal Engineering } \\
\text { Research Center (2002) } \\
\mathrm{L}_{\mathrm{w}} \text { - Coastal Engineering } \\
\text { Research Center (1984) } \\
\text { - shallow-water wave }\end{array}$ & & \\
\hline
\end{tabular}

Fig. 5. Areas of sediment resuspension determined using two models for calculating effective wind length and two models for determining the wind wave wavelength $\left(L_{w}\right)$ 
The respective percentages for Lake Wielgie (Dobiegniewskie) were lower due to the shape of the lake basin: 8.8 and $10.1 \%$.

Application of Model B for simulating the wind wave wavelength (CERC 1984) resulted, for both lakes, in a marked decrease of the area of the lake bed where resuspension was potentially possible. Depending on the model used for calculating the wind fetch length (Model 1 or Model 2), the following values were obtained, respectively: 3.0 and $3.0 \%$ for Lake Otalżyno, and 2.6 and $3.0 \%$ for Lake Wielgie. The fact that for both lakes the areas undergoing resuspension determined using Model B were similar and relatively low might suggest that both lakes have a similar basin geometry. This, however, is not the case. Lake Otalżyno has a flattened bed, while Lake Wielgie is characterised by considerable slopes of the bed, especially in the littoral zone (Fig. 5). Using Model B for simulating the resuspension areas in the studied lakes may therefore be unjustified.

Simulations carried out using the proposed methods demonstrated therefore that selection of the model (Model A and Model B) for determining the wind wave wavelength $\left(L_{w}\right)$ had the greatest impact on the resulting values. When we calculated the effective wind fetch length using Model 1 (BEB 1962), the differences in the percentage of the lake-bed area subjected to resuspension calculated using Model A (CERC 1975) and Model B (CERC 1975) were 13.3\% for Lake Otalżyno and 6.2\% for Lake Wielgie (Table 2). When we used Model 2 (CERC 2000) for calculating the effective wind length, the respective differences were 11.9 and $7.1 \%$.

Manipulation with the models used for calculating effective wind length (Model 1 and Model 2) with simultaneous preservation of a model for calculating the wind wave wavelength (Model A and Model B), yields very similar results defining the percentage of the lake bed which may be subject to resuspension processes. For Model A (CERC 1975), the difference between Models 1 and 2 was 1.4\% for Lake Otalżyno and only $1.2 \%$ for Lake Wielgie. When using Model B (CERC 1984) for calculating wind fetch, a difference $(0.4 \%)$ was only observed for Lake Wielgie (Table 2 ).

The methodology we adopted - without taking into account the effect of other external factors affecting wind-induced wave generation and propagation in Lake Otalżyno and Lake Wielgie - allowed us to obtain a representation of the spatial diversity of its fragments where sediment resuspension could be oc- curring. Eastern parts of the coastal zone are the areas most prone to wind-induced waving that causes lakebed sediment resuspension in Lake Wielgie (Fig. 5). In Lake Otalżyno, on the other hand, wind-induced resuspension of the lake-bed sediment occurs along the entire shoreline (Fig. 5). It should, however, be pointed out that the change in the calculation method (Table 2) did not significantly affect the spatial distribution of the areas prone to wind-induced lake-bed sediment $r$

\section{Discussion}

Simulations of processes occurring in lakes have been widely covered in international literature (e.g. Hawley and Lesht 1992; Hamilton and Mitchell 1996; Laenen and Le Torneau 1996; Bachmann et al. 2000; Booth at el. 2000; Cozar et al. 2005; Eleveld 2012). The repetitiveness of computations, especially in complex models, very often causes problems in making them attractive. The geoinformation techniques we used in our paper, employing elements of scripting, demonstrate that the modelling of processes associated with the functioning of the lake becomes much easier. The attractiveness of the model may be evidenced by its universality, which is affected by the short time needed to carry out the simulation process. We conducted a total of 8 simulations in our study. Each of the simulations, depending on the input parameters, took up to a 10 minutes to complete. Therefore, the proposed methodology for simulating the lake-bed sediment resuspension processes meets the criteria for being considered universal. Another point of the model's attractiveness is its applicability. Lake-bed sediment resuspension is one of the elements determining the rate of change in the quality of lake waters. Because resuspension processes play a significant role in the functioning of lakes, application of a method which can simulate them has a great practical value.

The parameters of the lake that most affect the presence of areas subject to resuspension are: wind direction and lake basin morphometric characteristics. The most significant morphometric elements are the area of the water body, which determines the fetch length, and its depth. Håkanson (1982) used both of these parameters to define the dynamic ratio $(D R)$ of the lake as the quotient of the square root of the lake area $A\left(\mathrm{~km}^{2}\right)$ and the mean depth $h_{m}(\mathrm{~m})$ of the water body $\left(D R=\sqrt{\mathrm{A}} / h_{m}\right)$.

Bachmann et al. (2000) conducted a study on a group of 62 shallow-water lakes in Florida and dem- 
onstrated that the dynamic ratio of the lake is strongly correlated with the percentage area of the lake bed subjected to the effects of wind-induced waves. Bachman employed a methodology in which the effective wind fetch was calculated from Model 1, and the wind wave wavelength was calculated from Model A. For the lakes of Florida, the threshold value of the dynamic ratio above which the entire water body was subjected to resuspension processes was 0.8 . The simulations in Lake Otalżyno and Lake Wielgie using Method 1A due to the small number of sampled water bodies and the fact that the simulation was carried out for only one wind direction and one average wind speed cannot unequivocally confirm the results obtained by Bachmann. Nevertheless, our study confirms the directly proportional relationship between the dynamic ratio of the lake and the percentage area of the lake bed subject to resuspension. The higher the DR, the larger the percentage of the lake bed where resuspension occurred (Table 2).

The results obtained using the applied procedure for determining resuspension areas indicate that the element that evidently differentiates the simulations performed is the method for calculating the wind wave wavelength $\left(L_{w} L_{w}\right)$ (Model A and Model $B)$. The selection of the model for calculating effective fetch (Model 1 and Model 2) plays a much smaller, if not negligible, role. It is not possible to unequivocally determine which of the methods is suitable for studied lakes without verification of the results. It may only be supposed that methods $1 \mathrm{~A}$ and $2 \mathrm{~A}$, which employ the CERC (1975) model for calculating the wind wave wavelength, provide more reliable results that primarily take into account the morphometric diversity of the lakes. This is consistent with the studies conducted on shallow-water lakes by Carper and Bachmann (1984), Scheffer (1998), Bachmann et al. (2000), Nagid et al. (2001) and Sarà (2009). That is why the next step of our research will involve an attempt to verify our methods. It will take into account the actual range of wind-induced waves which cause resuspension of lake-bed sediment.

An element that supports our procedure for determining resuspension areas, which seems to be a promising parameter for describing the susceptibility of lakes to distortion (mixing) of sediment caused by wind-induced waves, is the lake's dynamic ratio (Håkanson 1982, 2004; Bachmann et al. 2000). Bachmann (2000) proved in his study that the dynamic ratio was strongly correlated with the percentage area of the lake bed subjected to the mixing processes caused by wind-induced waves. For Lake Otalżyno and Lake Wielgie the values of this parameter also show a direct proportional relationship with the area of the lake bed subjected to resuspension. However, in order to be able to draw any firm conclusions on a strong correlation simulation analyses would be required for a much larger group of lakes and such simulations would need to be carried out for variable wind conditions (simulation at different wind directions and wind speeds).

Studies by Whitmore et al. (1996) and Bachmann et al. (2000) carried out on lakes in Florida show that the dynamic ratio of the lake is correlated with the parameters that describe the water quality in the lake. It may be assumed that the higher the dynamic ratio, the lower the quality of lake water, as expressed by phosphorus content, nitrogen content, chlorophyll concentration and transparency determined using the Secchi disc method.

The proposed methodology for determining areas of sediment resuspension in the lake, in conjunction with the lake's dynamic ratio and the parameters describing the quality of lake water, are tools on the basis of which the susceptibility to lake-bed sediment resuspension may be determined. As a result, it is possible to indicate those water bodies in which it is justified to undertake actions to limit the amounts of biogenic substances entering the water from sediment (internal loading).

\section{References}

Bachmann R.W., Hoyer M.V., Canfield D.E. Jr., 2000, The potential for wave disturbance in shallow Florida lakes, Lakes Reserv. Manage. 16(4): 281-291.

Bajkiewicz-Grabowska E., 1981, The influence of the physical geographic environment on the biogenous matter delivery to the lake, J. Hydrol. Sci. 8(1-4): 63-73.

Bajkiewicz-Grabowska E., 1983, Ecological characteristics of lakes in North-Eastern Poland versus their trophic gradient. II. Lake catchment areas - physico-geographical environment description of the region and 43 lakes, Ekol. Pol. 31(3): 257-286.

Bajkiewicz-Grabowska E., 1985, Struktura fizycznogeograficzna zlewni jako podstawa oceny dostawy materii biogennej do jezior (Effect of the physical geographic environment on the biogenous matter delivery to the lake), Pr. Stud. Geogr. 7: 65-88 (in Polish, English summary).

Bajkiewicz-Grabowska E., 2002, Obieg materii w systemach rzeczno-jeziornych (Circulation of matter in river-lake systems), Wydaw. UW, Warszawa, 274 pp. (in Polish, English summary). 
Bajkiewicz-Grabowska E., 2010, Assessment of the ecological state of lakes as proposed by the Polish Limnological Society, Limnol. Rev. 10(3-4): 105-116.

Bajkiewicz-Grabowska E., 2015, Jak ograniczenie presji środowiskowych do poziomu tolerancji jeziora wpływa na wskaźniki stanu trofii jego wód (The impact of reducing a lake's environmental pressures to its tolerance level on the lake's trophic state indices), [in:] Wiśniewski R. (ed.), Ochrona i rekultywacja jezior (Protection and restoration of lakes), PZIiTS, Toruń: 9-17.

Bajkiewicz-Grabowska E., Markowski M., 2014, Analiza hydrologiczna jeziora Wielgie Dobiegniewskie (Hydrological analysis of the Lake Wielgie Dobiegniewskie) [typescript], Katedra Limnologii UG, Gdańsk, 36 pp. (in Polish).

Bajkiewicz-Grabowska E., Mikulski Z., 1999, Hydrologia ogólna (General Hydrology), Wydaw. Nauk. PWN, Warszawa, 339 pp. (in Polish).

[BEB] Beach Erosion Board, 1962, Waves in inland resrvoirs, Technical Memo. 132, US Army Corps of Engineers, Washington, $128 \mathrm{pp}$.

Bengtsson L., Hellström T., 1992, Wind-induced resuspension in a small shallow lake, Hydrobiologia 241: 163-172.

Booth J.G., Miller R.L., McKee B.A., Leathers R.A., 2000, Wind-induced bottom sediment resuspension in a microtidal coastal environment, Cont. Shelf Res. 20: 785806.

Boström S., Jansson M, Forsberg C., 1982, Phosphorus release from lake sediments, Arch. Hydrobiol. Beih Ergebn. Limnol. 18: 5-39.

Carper G.L., Bachmann R.W., 1984, Wind resuspension of sediments in a prairie lake, Can. J. Fish. Aquat. Sci. 41(12):1763-1767.

[CERC] Coastal Engineering Research Center, 1975, Shore protection manual. Vol. I, U.S. Army Coastal Engineering Research Center, Fort Belvoir, 532 pp.

[CERC] Coastal Engineering Research Center, 1977, Shore protection manual. Vol. I, U.S. Army Coastal Engineering Research Center, Fort Belvoir, 532 pp.

[CERC] Coastal Engineering Research Center, 1984, Shore protection manual. Vol. I, Department of the Army, Waterways Experiment Station, Corps of Engineers, Vicksburg, 656 pp.

[CERC] Coastal Engineering Research Center, 2002, Shore protection manual. Vol. I, Business Books, 532 pp.

Cozar A., Galvez J.A., Hull V., Garcia C.M., Loiselle S.A., 2005, Sediment resuspension by wind in a shallow lake of Esteros del Iberá (Argentina): a model based on turbidimetry, Ecol. Model. 186(1): 63-76.

De Vicente I., Amores V., Cruz-Pizarro L., 2006, Instability of shallow lakes: A matter of the complexity of factors involved in sediment and water interaction?, Limnetica 25(1-2): 253-270.

Douglas R.W., Rippey B., 2000, The random redistribution of sediment by wind in a lake, Limnol. Oceanogr. 45(3): 686-694.
Ekholm P., Malve O., Kirkkala T., 1997, Internal and external loading as regulators of nutrient concentrations in the agriculturally loaded Lake Pyhäjärvi (southwest Finland), Hydrobiologia 345: 3-14.

Eleveld M.A., 2012, Wind-induced resuspension in a shallow lake from Medium Resolution Imaging Spectrometer (MERIS) full-resolution reflectances, Water Resour. Res. 48(4): 1-13.

Hamilton D.P, Mitchell S.F., 1996, An empirical model for sediment resuspension in shallow lakes, Hydrobiologia 317:209-220.

Hawley N., Lesht B.M., 1992, Sediment resuspension in Lake St. Clair, Limnol. Oceanogr. 37(8): 1720-1737.

Håkanson L., 1977, The influence of wind, fetch, and water depth on the distribution of sediments in Lake Vänern, Sweden, Can. J. Earth Sci. 14(3): 397-412.

Håkanson L., 1982, Lake bottom dynamics and morphometry: the dynamic ratio, Water Resour. Res. 18(5): 14441450.

Håkanson L., 2004, Lakes: Form and function, Blackburn Press, Caldwell, 201 pp.

James W.F., Barko J.W., 1994, Macrophyte influences on sediment resuspension and export in shallow impoundment, Lake Reserv. Manage. 10(2): 95-102.

Kajak Z., 1998, Hydrobiologia-Limnologia. Ekosystemy wód śródlądowych (Hydrobiology-Limnology. Ecosystems of inland waters), Wydaw. Nauk. PWN, Warszawa, 355 pp. (in Polish).

Kristensen P., Søndergaard M., Jeppesen E., 1992, Resuspension in a shallow eutrophic lake, Hydrobiologia 228: 101-109.

Laenen A., Le Tourneau A.P., 1996, Upper Klamath Basin nutrient-loading study: Estimate of wind-induced resuspension of bed sediment during periods of low lake elevation, U.S. Geological Survey Open-File Report 95414, Portland, 11 pp.

Leuttich R.A., Harleman D.R.F., Somlyody, L., 1990, Dynamic behaviour of suspended sediment concentrations in a shallow lake perturbed by episodic wind events, Limnol. Oceanogr. 35(5): 1050-1067.

Markowski M., Kwidzińska M., 2015, Types of geoecosystems of the lobelia lakes of the Tricity area, Quaest. Geogr. 34(1): 15-25.

Nagid E.J., Canfield D.E., Hoyer, M.V., 2001, Wind-induced increases in trophic state characteristics of a large (27 $\mathrm{km}^{2}$ ), shallow (1.5 mean depth) Florida lake, Hydrobiologia 455: 97-110.

Sarà G., 2009, Variation of suspended and sedimentary organic matter with depth in shallow coastal waters, Wetlands 29(4): 1234-1242.

Scheffer M., 1998, The Ecology of shallow lakes, Chapman \& Hall, London, 358 pp.

Smith I.R, Sinclair I.J., 1972, Deep water waves in lakes, Freshwater Biol. 2(4): 387-399.

Søndergaard M, Kristensen P., Jeppesen E., 1992, Phosphorus release from resuspended sediment in the shallow and wind-exposed Lake Arresø,Denmark, Hydrobiologia 228: 91-99. 
Van Hullebush E., Chatenet P., Deluchat V., Chazal P.M., Froissard D., Botineau M., Ghestem A., Baudu M., 2003, Copper accumulation in a reservoir ecosystem following copper sulfate treatment (St. Germain Les Belles, France), Water Air Soil Poll. 150(1-4): 3-22.

Ward Jr. G. H., 1980, Hydrography and circulation processes of Gulf estuaries, [in:] Hamilton P., MacDonald K.B. (eds), Estuaries and Wetland Processes with Emphasis on Modeling, Plenum Press, New York: 183-215.

Watts C.J., 2000, Seasonal phosphorus release from exposed, re-inundated littoral sediments of two Australian reservoirs, Hydrobiologia 431: 27-29.
Wetzel R.G., 2001, Limnology. Lake and river ecosystems, Academic Press, New York, 1006 pp.

Whitmore T.J., Brenner M., Schelske C.L., 1996, Highly variable sediment distribution in shallow, wind-stressed lakes: a case for sediment-mapping surveys in paleolimnological studies, J. Paleolimnol. 15(3): 207-221.

Wiśniewski R., 1995, Rola resuspensji osadów dennych w funkcjonowaniu ekosystemów wodnych (The role of bottom sediment resuspension in the functioning of aquatic ecosystems), Wydaw. UMK, Toruń, 102 pp. (in Polish). 